\title{
Histoanatomy and surface ultrastructure of the olfactory organ of the freshwater tank goby, Glossogobius giuris (Hamilton, 1822)
}

\author{
Saroj Kumar Ghosh
}

Received - 09 July 2020/Accepted - 07 September 2020. Published online: 30 September 2020; Inland Fisheries Institute in Olsztyn, Poland Citation: Ghosh S.K. 2020 - Histoanatomy and surface ultrastructure of the olfactory organ of the freshwater tank goby, Glossogobius giuris (Hamilton, 1822) - Fish. Aquat. Life 28: 141-148

\begin{abstract}
Characteristic features of histology and fine morphology of the olfactory organ in the tank goby, Glossogobius giuris (Perciformes, Gobiidae, Gobiinae), were investigated with light and scanning electron microscopy. The olfactory cavity contained single lamellae that were exposed to the aquatic environment by small anterior and posterior nostrils. Typical olfactory rosettes were not observed. Histologically, each lamella consisted of two layers of epithelium; wrapping the central core that was composed of connective tissue stroma with nerve fibers and blood capillaries. The mucosal lining of lamella was merged with sensory and non-sensory olfactory cells, identified on the basis of structural characters, surface specializations, and staining features. The principal sensory elements were ciliated receptor cells that were characterized by apical dendritic processes expanded from cell soma and microvillous receptor cells equipped with multiple tiny dendrons on the mucosal surface. The bead-like appearance of several labyrinth cells, mucous cells with secreted mucin, scattered lymphatic cells, stratified epithelial cells bearing microfolds, and condensed ciliated supporting cells were observed in the non-sensory epithelia. Undifferentiated basal cells were embedded in the deeper zone of the epithelium above the basement membrane. The cellular organization of the olfactory lining was interpreted with chemoreception of the fish concerned.
\end{abstract}

Keywords: Gobiid fish, olfactory structure, morphoanatomy, histology, olfaction

\footnotetext{
S. K. Ghosh [ڤ"]

Department of Zoology, Bejoy Narayan Mahavidyalaya, Itachuna, Hooghly-712 147, West Bengal, India

E-mail: saroj.fisherylab@gmail.com
}

\section{Introduction}

In fish, the olfactory and gustatory chemosensory pathways are important for the detection and recognition of chemical cues in the aquatic surroundings (Hara and Zielinski 1989). Olfactory responses enable fish species to detect food, escape from predators or enemies, identify sexual partners at breeding sites, and communicate with conspecifics in the aquatic environment (Hansen and Reutter 2004). The chemosensory organs are well developed and play significant roles for nocturnal species or those who live in dark aquatic habitats or inhabit muddy waters. Olfaction is considered as the first range for behavioral adaptations and function as distance sense (Devitsina and Chervova 1994). Diversity exists concerning the shape, morphology, lamellar arrangement, and cellular components of the olfactory organs among teleosts with regard to ecological behavior and mode of life. Sensory receptor cells having either apical cilia or microvilli on the olfactory epithelial surface are usual in fishes (Diaz et al. 2002, Chakrabarti and Guin 2011, Mokhtar and Abd-Elhafeez 2014, Malick et al. 2018, Ghosh 2020), furthermore, a third type, crypt receptor cells, are observed in some teleosts (Hamdani et al. 2008, Camacho et al. 2010, Chakrabarti and Ghosh 2011) with distinct sensitivity to alien stimuli. Only a few 
studies have been performed on the olfactory apparatus of gobiid fishes (Belanger et al. 2003, Arvedlund 2007, Kuciel et al. 2013, Kim et al. 2018, Sarkar et al. 2020). However, lacunae still exist in the detailed structure of olfactory organ in Gobiidae. Therefore, it would be interesting and informative to consider the olfactory system of Gangetic gobiid teleosts.

The tank goby, Glossogobius giuris (Hamilton) is a predatory benthopelagic teleost; its food items mostly include small fishes, mollusks, worms, insects, crustaceans and other zooplanktons (Roshni et al. 2015, Rama Rao et al. 2017). The present investigation is an attempt to describe the characteristic features of the olfactory organ in the G. giuris by staining and ultrastructural techniques.

\section{Materials and methods}

\section{Sample acquisition}

Adult specimens of G. giuris (12.7 to $22.6 \mathrm{~cm}$ in total length; $n=16$ ) were collected with cast and drag nets from the Bhagirathi-Hooghly River, a tributary channel of the Ganga River near Dhatrigram (Latitude $23.2796^{\circ} \mathrm{N}$, Longitude $88.3130^{\circ}$ E) of Purba Bardhaman, West Bengal. The samples were identified following key to classification of fishes by Misra (2003). After being anaesthetized with an ethyl 3-aminobenzoate methanesulfonate (MS-222; Merck) solution (100 $\mathrm{mg} \mathrm{l}^{-1}$ ), the fishes were sacrificed following the guidelines of the institutional animal ethics committee. The olfactory organs were dissected from the olfactory pits under a stereoscopic binocular microscope (Magnus MS24) and processed for the two techniques.

\section{Histology technique}

Olfactory tissues were fixed with Bouin's aqueous solution overnight. The fixed samples were washed well in $70 \%$ ethanol, dehydrated through a graded ethanol series, cleared in methyl benzoate and embedded in paraffin wax $\left(56-58^{\circ} \mathrm{C}\right.$, Sigma-Aldrich). Serial transverse $(0.4 \mu \mathrm{m})$ sections were obtained using a rotary microtome (Weswox MT-1090A Senior). Sections were stretched on albuminized glass slides, deparaffinized, and hydrated in descending graded ethanol series to distilled water. Tissue sections were stained with Delafield's Hematoxylin-Eosin (HE) (Fischer et al. 2008) and Romies Azan (RA). The staining slides were observed and photographed under a light microscope (Carl ZEISS Primo Star) equipped with a microscope camera (Tucsen 5.0 MP).

\section{Scanning electron microscopy technique}

After dissection, the olfactory organs were rinsed in a solution containing $2.5 \%$ glutaraldehyde buffered with $0.1 \mathrm{M}$ phosphate buffer ( $\mathrm{pH}$ 7.4) for 15-20 min. The olfactory organs were removed carefully from the olfactory pits and washed thoroughly with a $1 \%$ polyoxyethylenesorbitan monopalmitate solution (Tween 40; Merck) for $5 \mathrm{~min}$ to remove excess mucus and debris from the surface. The samples were immersed in the same buffer, transferred in 2.5\% glutaraldehyde for $24 \mathrm{~h}$ at $4^{\circ} \mathrm{C}$, and post-fixed in $1 \%$ $0.1 \mathrm{M}$ phosphate buffered osmium tetroxide (OsO4; Sigma-Aldrich) ( $\mathrm{pH}$ 7.4) for $2 \mathrm{~h}$ more at room temperature. After dehydration in an acetone series followed by isoamyl acetate, the samples were dried with liquid $\mathrm{CO}_{2}$ (using K850 Critical point dryer, Electron Microscopy Sciences) and mounted on aluminium pin stubs. After being sputtered (by BT-150 Sputter coater, Hind High Vacuum Co. Pvt. Ltd.) with platinum $(15 \mathrm{~nm})$, the specimens were examined with a scanning electron microscope (ZEISS EVO 18).

\section{Results}

\section{Gross anatomy}

G. giuris (Fig. 1A) had a pair of nasal chambers located dorsally on the snout, anterior to the eyes (Fig. 1B). The location of each nasal cavity was marked externally by small anterior and posterior 


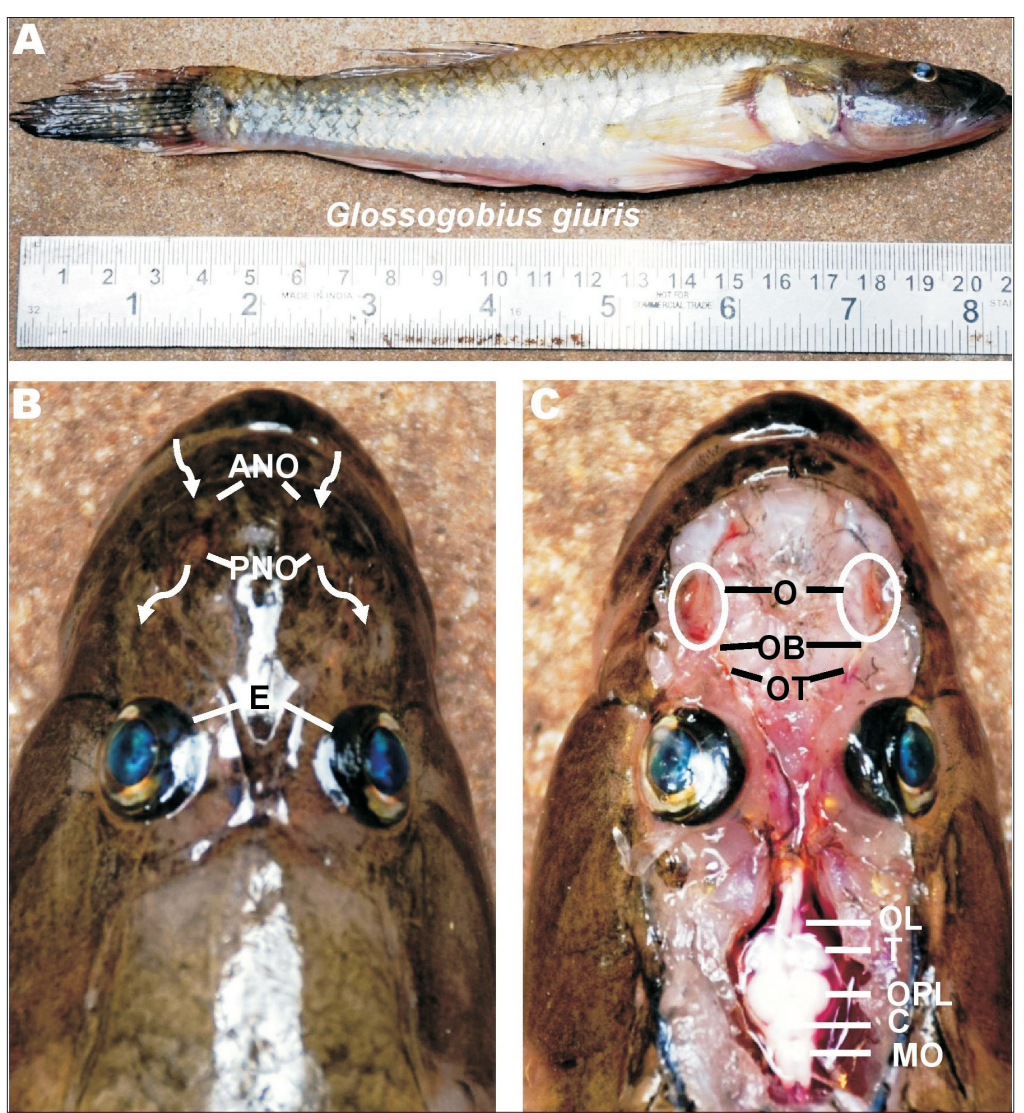

Figure 1. Photographs show the olfactory structure in G. giuris. (A) Lateral view of Glossogobius giuris. (B) Dorsal view of head exhibits olfactory pits with anterior nasal opening (ANO) and posterior nasal opening (PNO) distinguished by a skin fold. Arrows mark the pathway of water current through nostrils and $\mathrm{E}$ for eye. (C) Anterofrontal view of head displays the olfactory organ $(\mathrm{O})$, olfactory bulb $(\mathrm{OB})$, olfactory tract (OT), and the relationship between the brain and the olfactory lobe (OL), telencephalon (T), optic lobe (OPL), cerebellum (C) and medulla oblongata (MO).

openings, with a relatively small distance between them. Both the apertures were ovoid in outline and separated by a delicate nasal bridge. Through these two apertures, the water flow entered through the anterior nostril and existed over posterior the nostril. The bent nasal tube formed a tilt with the floor of the nasal chamber. The olfactory apparatus consisted of the olfactory chamber, the nostrils, the olfactory organ, the olfactory bulb, the olfactory tract, and the olfactory lobe. It was notable that there was no olfactory rosette, but a single lamella represented the laminate olfactory structure. The olfactory organs remained buried in the bottom of the olfactory chamber that was adhered to the surrounding skull bones by connective tissue fibres (Fig. 1C). The olfactory bulbs were poorly developed. The prolonged olfactory tracts arose from the ventral surface of the olfactory bulbs and terminated in the olfactory lobes of the telencephalon.

\section{Histomicroscopy}

The olfactory lamella was composed of double layers of stratified epithelium that enclosed the stromal stratum, the central core that consisted of fibrous connective tissues with blood capillaries and nerve fibers. The epithelial lining was isolated from the central core by a thin basement membrane (Fig. 2A). The olfactory epithelium contained architecturally specific ciliated receptor cells, microvillous receptor cells, labyrinth cells, lymphatic cells, mucous cells, basal cells, and two kinds of supporting cells that were either of the nonciliated oval type or ciliated columnar non-sensory cells.

The ciliated receptor cells were characterized by deeply stained elliptical nuclei and cylindrical dendrites facing toward the epithelial border, closely arranged in a single row (Figs. 2B and C). The distal tip of the dendrite had a small swelling, the olfactory knob, which was embossed with poorly visible fine hairs on the mucosa (Fig. 2B). These sensory cells appeared as bipolar neurons with dendritic terminations in some regions of the mucosa (Fig. 2A). Microvillous receptor cells were more peripheral in the olfactory lining and were depicted with moderately stained round nuclei and flat surfaces (Figs. 2B). Labyrinth cells were dispersed randomly in the mucosal margin. They were fairly large and bulbous in appearance with medially placed basophilic nuclei (Figs. 2A-C). Lymphatic cells were distributed throughout the epithelium, had prominent nuclei and granulated cytoplasm. Empty mucous cells were ellipsoidal in outline, and they released their content on the 


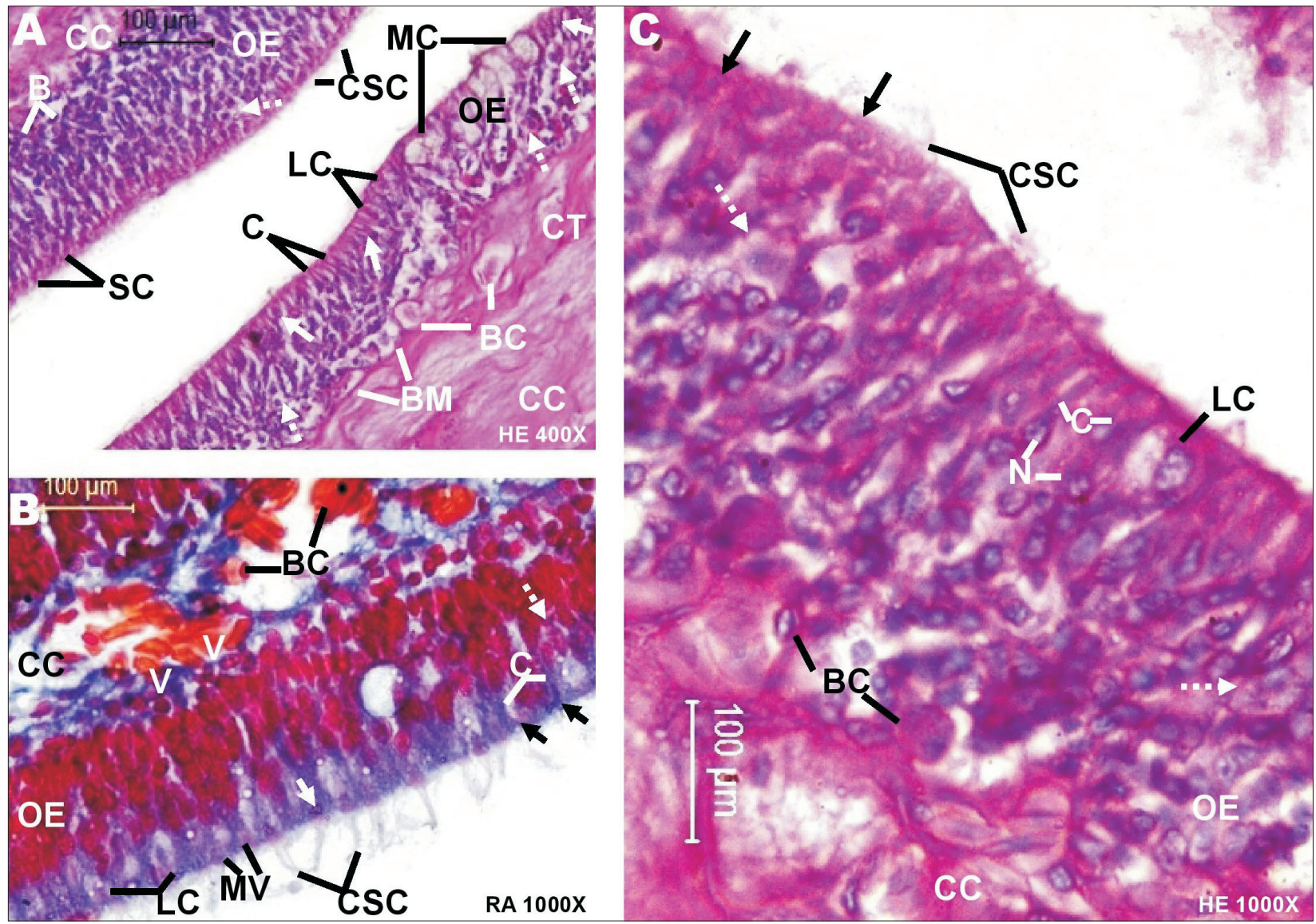

Figure 2. Transverse section of olfactory lamella of G. giuris stained with Delafield's Hematoxylin-Eosin (HE) and Romies Azan (RA). (A) Olfactory epithelium (OE) consists of ciliated receptor cells (C), labyrinth cells (LC), mucous cells (MC), basal cells (B), lymphatic cells (broken arrows), ciliated (CSC) and nonciliated (SC) supporting cells. Note the presence of the basement membrane (BM) between the epithelium and the central core (CC), which contains blood capillaries (BC) and fibrous connective tissue (CT). Arrows indicate bipolar neurons. (B) Olfactory epithelium (OE) shows ciliated receptor cells (C) with apical swellings (solid arrows), microvillous cells (MV), labyrinth cells (LC), lymphatic cells (broken arrows), ciliated supporting cells (CSC), and basal cells (arrow heads). The central core (CC) contains blood cells (BC). (C) Magnified epithelium (OE) illustrates ciliated receptor cells (C) bearing nuclei (N), labyrinth cell (LC), lymphatic cells (broken arrows), ciliated supporting cells (CSC), and stratified epithelial cells (solid arrows). Note the presence of blood cells (BC) in the central core (CC).

mucosal surface (Fig. 2A). The polygonal basal cells appeared as stem cells that contained distinct immense nuclei, embed deep in the mucosa adjacent to the basement membrane (Figs. 2A and B). The nonciliated supporting cells with dark central nuclei spread overall the mucosa (Figs. 2A and C). Diffused ciliated supporting cells were columnar in pattern with a flat surface adorned with cilia (Figs. 2B and C).

\section{Scanning electron microscopy}

Each olfactory cavity held a single lamella and the regular olfactory rosette was lacking. The lamella had a folded, thick perpendicular structure that was aligned on the longitudinal axis of the nasal chamber. The lamella had a poorly developed base that was the olfactory bulb associated with the olfactory tract (Fig. 3A). Sensory and non-sensory olfactory cells were discontinuously distributed over the mucosa (Fig. 3B). Receptor cells were not confined in a specific region. Based on surface structural characteristics, the sensory neurons were classified as ciliated and microvillous receptor cells. Ciliated receptor cells had narrow hillock-like attenuated tips originating from the periphery, whereas microvillous receptor cells were covered with condensed 

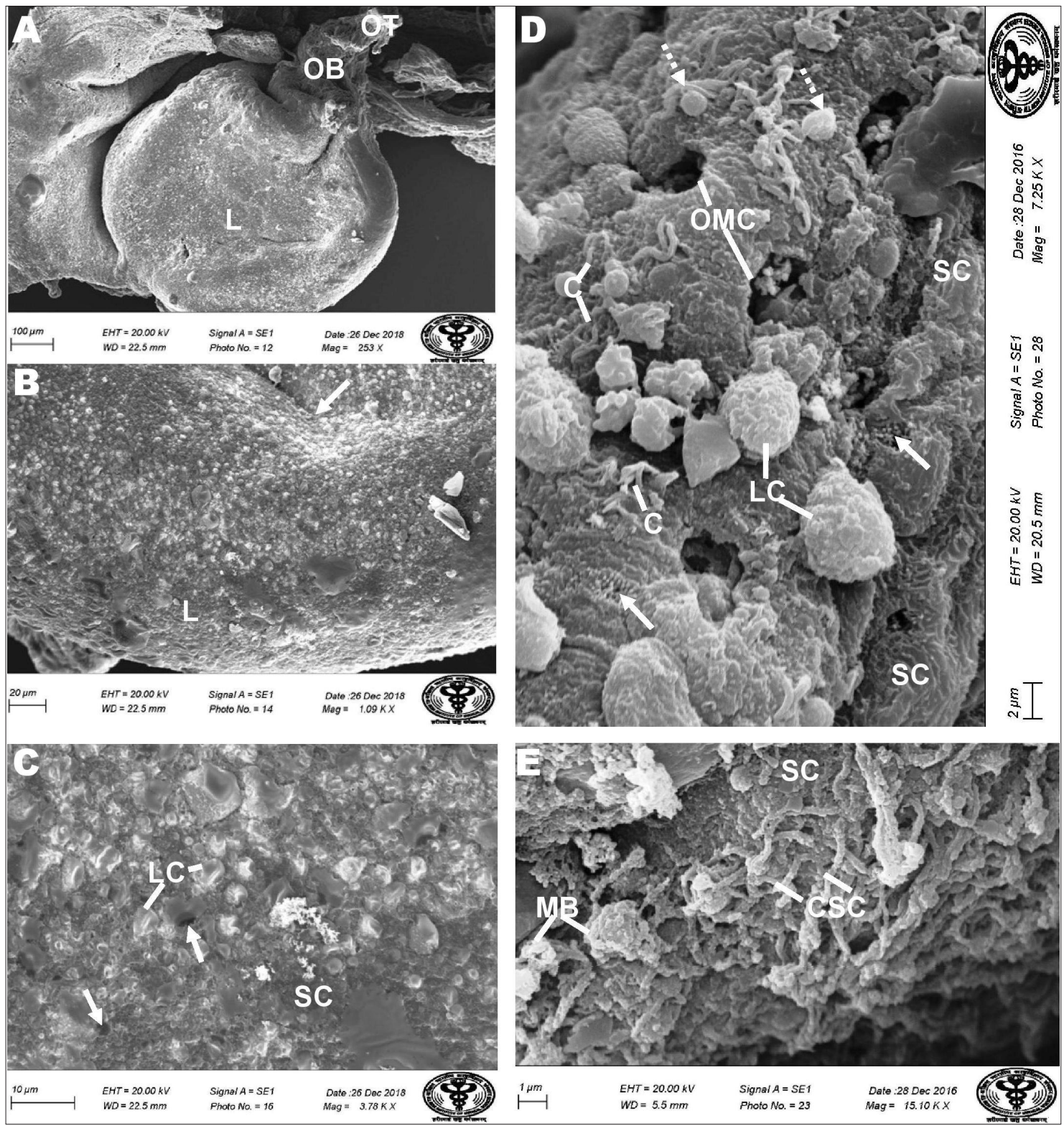

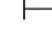

Figure 3. Surface view of olfactory lining of G. giuris with scanning electron microscopy. (A) Structure of the olfactory lamella (L) along with poorly a developed olfactory bulb (OB) and olfactory tract (OT). (B) Olfactory lamella (L) lines with various sensory and non-sensory cells. Arrow marks folding of lamella. (C) Non-sensory mucosa contains a large number of labyrinth cells (LC), stratified epithelial cells (SC), and openings of mucous cells (arrows). (D) Surface of lamella shows sensory epithelium with ciliated receptor cells (C), microvillous receptor cells (solid arrows), and the non-sensory epithelium contains stratified epithelial cells (SC) and labyrinth cells (LC). Note the presence of the opening of mucous ells (OMC) with mucus masses (broken arrows). (E) Magnified non-sensory mucosa shows dense ciliated supporting cells (CSC) and stratified epithelial cells (SC). MB indicates mucin balls.

microvilli-like organizations that exhibited harsh surfacing over the mucosa (Fig. 3D). The non-sensory epithelia were lined with a large number of labyrinth cells, secretory mucous cells, stratified epithelial cells bearing inconspicuous microfoldings and ciliated supporting cells. Labyrinth cells had a globular appearance with shallow infoldings (Figs. $3 \mathrm{C}$ and D). Irregularly occurring mucous cells had clear openings that ejected mucin over the stratified epithelial cells (Figs. 3C and D). Ciliated supporting cells were arranged in dense aggregation and dispersed among the stratified epithelial cells (Fig. 3E). 


\section{Discussion}

The structural modification and cellular nature of the olfactory organ in fishes was correlated with ecological habits and modes of life. The specialization of the olfactory system can occur in some teleosts through adaptations to particular environments. Although the olfactory rosette was absent in G. giuris, chemical stimuli were detected by the sensory receptor cells on the olfactory lamella and conveyed to the central nervous system by cranial nerve-I. The absence of the olfactory rosette was perhaps infrequent, and this was also observed in Periophthalmus barbarus (L.) (Kuciel et al. 2011). Olfaction in fish is commonly linked with water ventilation through the sniffing process (Nevitt, 1991). Water with odorants enters the nasal cavity through the anterior nostril and exists via posterior nostril, which bathes the olfactory lining.

The presence of a unilamellar olfactory organ, and, consequently, limited olfactory space in $G$. giuris could be correlated with feeding niches concerning the sense of smell. Therefore, this species could be categorized as Teichmann's (1954) second group of eye fishes, which depends more on vision. This kind of olfactory organ is classified into Pol Gerard's (1954) first category, i.e., anosmic, in which the olfactory sense is less necessary to locate food. Depending on lamellar arrangement, this type of olfactory organ is under the category of Type- $\mathrm{B}$, single within olfactory chamber classified by Yamamoto (1982). The efficiency of the olfactory organ was accomplished by the folding of the olfactory lamella, which enhanced its surface area. The occurrence of sensory and non-sensory cells on the lamellae exhibits immense diversity among teleostean fishes, which is linked with habits and behavior.

There are two morphological types of receptor cells: those with ciliated edges and those with microvillar tips. The receptor cells were sensory in nature and able to judge chemical cues from the surroundings. Similar types of receptor cells were also reported in other gobiid fishes (Kuciel et al. 2011, Kim and Park 2016). Hansen and Zeiske (1998) postulated that receptor cells containing odorant receptors exposed the stimuli and transmitted the message to the olfactory bulb. Zippel et al. (1997) reported that ciliated neurons were specific for amino acids, while microvillous cells communicated with pheromones. The olfactory knob with dendritic extensions and microvilli of receptor cells implied various useful activities and skill for the recognition of chemical cues (Hansen and Zielinski 2005).

The labyrinth cells on the olfactory mucosa might have served as excretory cells for osmoregulation and ion regulation. These cells were similar to chloride cells that were probably involved in electrolyte transport in fish gills and the pseudobranch (Bertmer, 1972). The presence of lymphatic cells throughout the epithelia functioned as a component of cell immunity (Lieschke and Trede 2009). The same cell types were reported in the olfactory organ of Micropterus salmoides (Lacepčde) (Kim et al. 2019). Mucous cells secreted mucin which protected the epithelia and helped to bind microscopic particles to keep the sensory receptor accessible for new odorants. Kasumyan (2004) reported that mucous cells discharged their contents when species suffered from polluted or dirty water. Stratified epithelial cells helped in mechanical dissociation and secreted substances over the olfactory lamella (Hara 1994). The cilia of supporting cells created a feeble current along the mucosa and guided the odorant molecules to contact with the tips of sensory neurons (Hara 2000). The cilia also propelled mucus over the lamella. Supporting cells further provided a scaffold for the olfactory epithelium. The basal cells were thought to be the progenitor cells of receptor and supporting cells (Zeiske et al. 1992). The occurrence of basal cells deep in the epithelia helped to sustain the mucosa during normal cell turn over or necrobiosis.

The absence of a rosette inside the olfactory sac was perhaps, unusual in fishes. However, a single unit of olfactory lamella covered with sensory and non-sensory cells was well defined in the present work. The olfactory response and chemical stimulation of the organism could be determined by suitable experimental works in future. 
Acknowledgements. The author is grateful to the authority of the Sophisticated Analytical Instrumentation Facility (SAIF), Department of Anatomy, All India Institute of Medical Sciences (AIIMS), New Delhi-110 029, India for technical support in scanning electron microscopy.

Conflict of interest. The author declares no competing interest regarding the publication of this manuscript.

Ethical statement. Not applicable. In India, researchers do not need permission to procure animals except when the geographical area from which they originate is in a wildlife protected area (The Gazette of India, REGD. NO. D. L.-33004/99; Section-17).

ORCID ID

Saroj Kumar Ghosh. (iD https://orcid.org/0000-0003-3973-8013

\section{References}

Arvedlund M., Munday P.L., Takemura A. 2007 - The morphology and ultrastructure of the peripheral olfactory organ in newly metamorphosed coral-dwelling gobies, Paragobiodon xanthosomus Bleeker (Gobiidae, Teleostei) - Tissue Cell. 39: 335-342.

Belanger R.M., Smith C.M., Corkum L.D., Zielinski B.S. 2003 - Morphology and histochemistry of the peripheral olfactory organ in the round goby, Neogobius melanostomus (Teleostei: Gobiidae) - J. Morphol. 257: 62-71.

Bertmar G. 1972 - Labyrinth cells, a new cell type in vertebrate olfactory organs - Z. Zellforsch. Mikrosk. Anat. 132: 245-256.

Camacho S., Ostos-Garrido M.V., Domezain A., Carmona R. 2010 - Study of the olfactory epithelium in the developing sturgeon characterization of the crypt cells - Chem. Senses. 35: 147-156.

Chakrabarti P., Ghosh S.K. 2011 - Histological and ultrastructural studies of the olfactory rosette of spotted butter fish Scatophagus argus (Linnaeus) - Folia Morphol. 70: 74-79.

Chakrabarti P., Guin S. 2011 - Surface architecture and histoarchitecture of the olfactory rosette of freshwater spiny eel, Macrognathus aculeatus (Bloch) - Arch. Pol. Fish., 19: 297-303.

Devitsina G.V., Chervova L.S. 1994 - Morphological and physiological aspects of fish chemoreception - In: Advances in fish biology (Ed.) H.R. Singh, Hindustan Publishing Corporation, Delhi: 185-191.

Diaz J.P., Prié-Granié M., Blasco C., Noëll T., Connes R. 2002 - Ultrastructural study of the olfactory organ in adult and developing European sea bass, Dicentrarchus labrax Can. J. Zool. 80: 1610-1622.

Fischer A.H., Jacobson K.A., Rose J., Zeller R. 2008 Hematoxylin and eosin staining of tissue and cell sections - Cold Spring Harb. Protoc. 3: 1-3.

Gerard P. 1954 - Organe olfactif - Traité de Zoologie 12: 522-533.

Ghosh S.K. 2020 - The olfactory organ in the Gangetic catfish, Ailia coila (Hamilton, 1822): structural and functional aspects - J. Fish. 8: 843-849.

Hansen A., Zeiske E. 1998 - The peripheral olfactory organ of the zebrafish, Danio rerio: an ultrastructural study Chem. Senses 23: 39-48.

Hansen A., Reutter K. 2004 - Chemosensory systems in fish: Structural, Functional and Ecological Aspects. In: The senses of fish (Eds) G. von der Emde, J. Mogdans, B.G. Kapoor, Springer, Dordrecht: 55-89.

Hansen A., Zielinski B.S. 2005 - Diversity in the olfactory epithelium of bony fishes: development, lamellar arrangement, sensory neuron cell types and transduction components - J. Neurocytol. 34: 183-208.

Hara T.J., Zielinski B. 1989 - Structural and functional development of the olfactory organ in teleosts - Trans. Amer. Micro. Soc. 118: 183-194.

Hara T.J. 1994 - The diversity of chemical stimulation in fish olfaction and gestation - Rev. Fish Biol. Fish. 4: 1-35.

Hara T.J. 2000 - Chemoreception. In: The laboratory fish (Ed.) G.K. Ostrander, Academic press, London: 471-479.

Kasumyan A.O. 2004 - The olfactory system in fish: Structure, function, and role in behavior - J. Ichthyol. 44: 180-223.

Kim H.T., Park J.Y. 2016 - The anatomy and histoarchitecture of the olfactory organ in Korean flat-headed Goby Lucigobius guttatus (Pisces; Gobiidae) - Appl. Microsc. 46: 51-57.

Kim H.T., Yun S.W., Park J.Y. 2018 - Functional anatomy and histology of the olfactory organ in Korean eel Goby, Odontamblyopus lacepedii (Pisces: Gobiidae) - Appl. Microsc. 48: 11-16.

Kim H.T., Yun S.W., Park J.Y. 2019 - Anatomy, ultrastructure and histology of the olfactory organ of the largemouth bass Micropterus salmoides, Centrarchidae Appl. Microsc. 49: 1-6.

Kuciel M., Żuwala K., Jakubowski M. 2011 - A new type of fish olfactory organ structure in Periophthalmus barbarous (Oxudercinae) - Acta Zool. 92: 276-280.

Kuciel M., Zuwala K., Satapoomin U. 2013 - Comparative morphology (SEM) of the peripheral olfactory organ in the Oxudercinae subfamily (Gobiidae, Perciformes) Zool. Anz. 252: 424-430.

Lieschke G.J., Trede N.S. 2009 - Fish immunology - Curr. Biol. 19: 678-682.

Malick C., Chatterjee S.K., Bhattacharya S., Suresh V.R., Kundu R., Saikia S.K. 2018 -Structural organization of 
the olfactory organ in an amphihaline migratory fish Hilsa, Tenualosa ilisha - Microsc. Res. Techniq. 81: 1122-1131.

Mira K.S. 2003 - An aid to the identification of the common commercial fishes of India and Pakistan - Narendra Publishing House, Delhi, India, 320 p.

Mokhtar D.M., Abd-Elhafeez H.H. 2014 - Light-and electron-microscopic studies of the olfactory organ of red-tail shark, Epalzeorhynchos bicolor (teleostei: cyprinidae) - J. Microsc. Ultrastruct. 2: 182-195.

Nevitt G.A. 1991 - Do fish sniff? A new mechanism of olfactory sampling in pleuronectid flounders - J. Exp. Biol. 157: 1-18.

Rama Rao K., Srivanthika G., Shivakumar B., Shivaji M., Sirisha A. 2017 - Ichthyo faunal diversity of Jammikunta mandal freshwater perennial tanks at Karimnagar district; Telangana State: India - Int. J. Fish. Aquat. Stud. 5: 383-391.

Roshni K., Renjithkumar C.R., Madhusoodana Karup B. 2015

- Food and feeding habits of Glossogobius giuris in
Chalakudy River, Southern Western Ghats, India - Int. J. Sci. Res. Sci. Eng. Technol. 1: 321-325.

Sarkar S.K., Jana S., De S.K. 2020 - Functional role of the rodlet cell and macrophage in neural protection of the olfactory neuroepithelium in a teleostean: Gobiid (Pseudapocryptes lanceolatus [Bloch and Schneider, 1801]): An ultrastructural study - J. Microsc. Ultrastruct. 8: 37-41.

Teichmann H. 1954 - Vergleichende Untersuchungen an der Nase der Fische - Z. Morphol. Oekol. Tiere 43: 171-212.

Yamamoto M. 1982 - Comparative morphology of the peripheral olfactory organ in teleosts. In: Chemoreception in fishes (Ed.) T.J. Hara, Elsevier, Amsterdam: 35-59.

Zeiske E., Theisen B., Breucker H. 1992 - Structure, development and evolutionary aspects of the peripheral olfactory system. In: Fish chemoreception (Ed.) T.J. Hara, Chapmann and Hall, London: 13-39.

Zippel H.P., Sorensen P.W., Hansen A. 1997 - High correlation between microvillous olfactory receptor cell abundance and sensitivity to pheromones in olfactory nerve-sectioned goldfish - J. Comp. Physiol. 180: 39-52. 